\title{
Effects of hyperglycemia and ageing on the healing of colonic anastomoses in rats ${ }^{1}$
}

\author{
Efeitos da hiperglicemia e do envelhecimento na cicatrização de anastomoses colônicas, em \\ ratos
}

\author{
Maria de Lourdes Pessole Biondo-Simões ${ }^{\mathrm{I},}$ Rachel Biondo-Simões $^{\mathrm{II}}$, Sergio Ossamu Ioshii ${ }^{\mathrm{III}}$, Daniel Sindelar Barczak ${ }^{\mathrm{IV}}$, Mariana \\ Rocha Tetillav \\ ${ }^{I}$ Full Professor, Scientific Methodology, PUCPR and Associate Professor, Department of Surgery, Federal University of Parana (UFPR), Brazil.

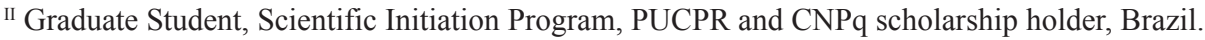 \\ III Associate Professor, Experimental Pathology, PUCPR and Department of Pathological Anatomy, UFPR, Curitiba-PR, Brazil. \\ Iv MD, PUCPR, Curitiba-PR, Brazil. \\ ${ }^{v}$ Graduate Student, Scientific Initiation Program, PUCPR, Curitiba-PR, Brazil.
}

\begin{abstract}
Introduction: Despite the significant advances in the knowledge of the healing process, there is a limited number of studies demonstrating the relationships of this healing with ageing and elevated levels of glycemia. Purpose: To evaluate the effects of ageing and hyperglycemia on the healing of colonic anastomosis. Methods: 138 young and old male rats were utilized. Some of them were normoglycemic and others had hyperglycemia induced by streptozocin $(50 \mathrm{mg} / \mathrm{kg})$. They were maintained under control for 90 days. They were then submitted to a termino-terminal anastomosis in the left colon. On the third, seventh and fourteenth days after surgery, their resistance was evaluated and a histopathological study of the anastomosis was carried out. Results: Gain in resistance was similar for both groups. The additive effect of age with hyperglycemia made a significant difference to the collagen I $(p<0.001)$, III $(p=0.022)$ and total $(\mathrm{p}<0.001)$. Among the old animals, the glycemia was a determining factor for the occurrence of a significant difference in total collagen $(p=0.029)$ and collagen I $(p=0.013)$. Among the normoglycemics, age determined a lower density of collagen I $(p=0.002)$. Conclusion: There is delayed collagen synthesis and maturation of the scars of older animals, a situation that becomes more serious in older hyperglycemic animals, but insufficient to adversely affect the gain in resistance.
\end{abstract}

Key words: Diabetes Mellitus, Experimental. Hyperglycemia. Collagen. Wound Healing. Colon. Anastomosis, Surgical.

\section{RESUMO}

Introdução: Apesar dos significantes avanços no conhecimento do processo cicatricial há um restrito número de estudos demonstrando as relações deste reparo com o envelhecimento e com níveis elevados de glicemia. Objetivo: Avaliar os efeitos do envelhecimento e da hiperglicemia na cicatrização de anastomoses colônicas. Métodos: Utilizaram-se 138 ratos machos, adultos jovens e velhos. Parte deles era normoglicêmico e parte teve hiperglicemia induzida pelo streptozocin $(50 \mathrm{mg} / \mathrm{kg})$. Foram mantidos controlados por 90 dias. Após fez-se uma anastomose término-terminal no cólon esquerdo. No $3 .^{\circ}, 7^{\circ}$ e $14 .^{\circ}$ dia de pós-operatório avaliou-se a resistência e fez-se o estudo histo-patológico da anastomose. Resultados: O ganho de resistência foi semelhante entre os grupos. O efeito aditivo da idade com a hiperglicemia determinou diferença significativa nos colágenos I ( $p<0,001)$, III $(p=0,022)$ e total ( $p<0,001)$. Entre os velhos a glicemia foi determinante para ocorrer diferença significativa no colágeno total $(p=0,029)$ e colágeno I $(p=0,013)$. Entre os normoglicêmicos a idade determinou menor densidade de colágeno I $(\mathrm{p}=0,002)$. Conclusão: Existe atraso na síntese do colágeno e na maturação das cicatrizes nos animais velhos, situação que se agrava nos animais velhos e hiperglicêmicos, não suficiente para prejudicar o ganho de resistência.

Descritores: Diabetes Mellitus Experimental. Hiperglicemia. Colágeno. Cicatrização de Feridas. Colo. Anastomose Cirúrgica.

${ }^{1}$ Research performed at Division of Research Methodology, PUC University of Paraná (PUCPR), Brazil.

\section{Introduction}

Healing can be affected by negative influences of many factors such as: disturbances of coagulation, metabolic disturbances such as diabetes and hypothyroidism, vascular alterations such as atherosclerosis, radiotherapy, the chronic use of medicines such as steroidal and non-hormonal anti-inflammatory drugs, advanced age, infection and others ${ }^{1}$. 
With the advance of age, it is common for the coexistence of diseases to affect the healing process. It has been shown that although there are differences in the healing process for colonic anastomoses in young and old rats, like the higher number of inflammatory cells and the higher deposition of collagen I in the post-surgery phase of anastomoses in young rats, age by and of itself did not cause the failure to heal ${ }^{2}$. Nevertheless, age did delay re-epithelization ${ }^{3}$.

Several factors are known to contribute to deficient healing in individuals with diabetes. These include: a reduction in the production of growth factors, angiogenic response, macrophage function, collagen accumulation, epidermal barrier function, quantity of granulation tissue, proliferation and migration of keratinocytes and fibroblasts, bean healing and the balance between the accumulation of extra (MMPs) ${ }^{3-12}$.

One of the greatest physio-pathological consequences of hyperglycemia is excessive chemical interaction of glucose with proteins, leading to their connection without the aid of enzymes, non-enzymatic glycosylation. It has been seen that diabetics glycosylated seric protein levels that are four times higher than normal individuals ${ }^{13}$. Short half-life proteins have a reversible reaction, therefore damage is limited and reversible in long half-life proteins there is greater accumulation of end products of glycosylation to a point that it is irreversible, leading to structural and functional alterations ${ }^{14}$.

Oxygen has greater affinity for glycosylated hemoglobins, which is reflected in alterations in the hemoglobin dissociation curve, resulting in reduced release of oxygen to the tissues ${ }^{15}$. As collagen synthesis is dependent on oxygen, healing in diabetics may be compromised.

Diabetic rats have been described as showing deficiency in the closing of cutaneous injuries, with delayed re-epithelization, prolonged inflammatory response, impoverished angiogenesis, reduced matrix deposition and less contraction of the injury ${ }^{16}$. In the same way that it affects healing at the cutaneous level, diabetes can also interfere negatively in the healing of the gastrointestinal tract ${ }^{17}$.

Studies of the healing of injuries in the stomach and duodenum of diabetic rats have shown that even when late, the wounds of these animals are less resistant and have lower quantities of total collagen when compared to normal diabetic animals controlled by the use of insulin ${ }^{18}$.

Researchers admit that the lower resistance of the anastomosis is not due to the amount of collagen but possibly to the alteration in the quality of the collagen fibers ${ }^{19,20}$. These authors have shown that diabetes caused structural deficiencies in the healing of intestinal anastomoses, even when the glucose level returned to normal with the use of insulin ${ }^{21}$.

In diabetic rats with gastric injuries there is reduced fibroblast growth factor (FGF), a potent angiogenic factor which is capable of stimulating other cells, like the fibroblasts, the smooth muscular cells and the epithelial cells ${ }^{22}$. The resistance of the anastomoses in diabetic rats was found to have been compromised, with less type I collagen accumulation on the seventh day after surgery ${ }^{23}$.

Most studies on diabetes and healing research the precocious effects of hypergylcemia on the healing process. The maintenance of endothelium and the integrity of microcirculation is very important since it is responsible for the transport and offer of nutrients and the removal of metabolites from the tissues ${ }^{15}$. Damage caused by hyperglycemia leads to important implications for transcapillary transport and the cirulation of endothelial products like the Von Willebrand factor and the angiotensin converter enzymes that can lead to platelet aggregation abnormalities and interfere in the inflammatory process of the healing ${ }^{15}$. Many of the complications of diabetes are the result of damage caused to the microcirculation vessels ${ }^{24}$.

High glucose concentrations activate the aldose reductate which converts glucose to sorbitol. This accumulates within the cells and leads to an osmotic movement of water to their interior, producing edemas and damaging the tissues. These elevations of pressure aggravate the lesions of the endothelial cells. The endothelial damage, repaired with an excess protein deposit in the basal membranes, added to the effect of protein kinase $C-\beta$, which stimulates the additional synthesis of these membranes and results in damage to the diapedesis of the leukocytes and the erythrocytes. These alterations account for the delayed inflammatory response $\mathrm{e}^{25,26}$. Furthermore, it has been shown through experiments that phagocytic capacity and the production of hydrogen peroxide are reduced in the neutrophils of diabetics ${ }^{27}$.

The Brazilian Diabetic Society informs us that $12 \%$ of people over the age of forty are diabetics. If we consider diabetics and pre-diabetics, this number rises to $19.8 \%$ of people aged thirty to sixty-nine ${ }^{28}$. Moreover, Brazilians are living longer. The average lifespan in 2006 was 72.3 years $^{29}$.

Colon cancer is the third most frequent in the world and the second in developed countries. In Brazil, the National Cancer Institute (INCA) calculates that there will be 12,490 new cases in men in 2008 and 14,500 in women ${ }^{30}$.

Therefore, if we consider the growing number of elderly people and the factors of diabetes and colon cancer, there is an evident need to study the healing process in these situations.

The aim of this study is to recognize the interferences caused to the collagen synthesis in colonic anastomoses by ageing and by hyperglycemia in animals.

\section{Methods}

The project was evaluated and approved by the Ethics in Research Committee at the PUC University (PUCPR), Report number 75/07, registration number 244 . The study followed the guidelines for animal research as set out by the Brazilian College of Animal Experimentation (COBEA).

The sample was made up of 138 male Wistar rats (Rattus norvegicus albinus, Rodentia mammalia), supplied by the PUCPR vivarium. Of these, 69 were between 100 and 120 days old (average age 112 days) and 69 were aged between 650 and 710 days (average age of 672 days). The weight of the young rats was 228.17 $\pm 20.34 \mathrm{~g}$ and the older ones weighed $364.48 \pm 20.96 \mathrm{~g}$. They were kept in groups of five per standard cage for the species at the Central Vivarium where the light-dark cycle was 12 hours and humidity was the same as a normal environment without any artificial regulation. The temperature was a constant $20 \pm 2^{\circ} \mathrm{C}$. The animals were fed standard commercial food and had free access to water throughout the experiment.

They were divided into four groups: young normoglycemic (YN, $\mathrm{n}=21)$, old normoglycemic $(\mathrm{ON}, \mathrm{n}=21)$, young hyperglycemic $(\mathrm{YH}, \mathrm{n}=48)$ and old hyperglycemic $(\mathrm{OH}, \mathrm{n}=48)$.

Glycemia was confirmed by a hemoglucotest. A drop of 
blood was collected from the end of the tail at the beginning of the study. The animals selected to belong to the hyperglycemic groups were weighed and received streptozocin (Zanosar ${ }^{\mathbb{B}}$; Upjohn CO.), $50 \mathrm{mg} / \mathrm{kg}$ of weight by endovenous injection utilizing the dorsal vein of the penis and those selected for the normoglycemic groups received a corresponding volume. New glycemia checks were made after twenty-four hours and after ninety days, prior to surgery.

An anesthetic by an intramuscular injection of $0.2 \mathrm{ml} / 100 \mathrm{~g}$ of weight from a mixture of $1 \mathrm{ml}$ of ketamine $(50 \mathrm{mg})$ and $1 \mathrm{ml}$ of xylazine $(20 \mathrm{mg})^{31}$. The trychotomy of the ventral abdominal wall was done and anti-sepsis with polyvinylpyrrolidone-iodine.

The surgical procedure consisted of a median laparotomy with four centimeters. The transverse colostomy was done at $2.5 \mathrm{~cm}$ from the peritoneal reflection, followed by termino-terminal anastomosis on a single sero-muscular layer with eight interrupted 5.0 monofilament nylon stitches. We then moved on to the laparorraphy at two levels: the first, peritoneal-muscularaponeurotic; the second, of the skin, with continuous synthesis, utilizing 4.0 monofilament nylon.

After recuperating from the anesthetic, the rats were returned to their cages, where they had free access to standard commercial food and water. Immediately after surgery they were given an intramuscular dose of sodium diclofenac at a dosage of $10 \mathrm{mg} / \mathrm{kg}$, as an analgesic and anti-inflammatory drug ${ }^{31}$.

The four groups were subdivided at random into three subgroups according to the date of euthanasia on the third, seventh and fourteenth days after surgery, for which a lethal dose of intraperitoneal sodium thiopental was used at $120 \mathrm{mg} / \mathrm{kg}^{32}$.

After euthanasia, another laparotomy was performed, enabling us to observe the abdominal cavity, the existence of peritonitis or abscess, adherences and the integrity of the anastomoses.

A four-centimeter segment of the colon was dries, containing anastomosis in the mid portion and a study of the resistance of anastomoses to insuflation, obtaining the pressure measurements at the time of rupture in millimeters of mercury.

After this evaluation, the surgical parts were opened lengthwise and extended on filter paper and set in 10\% formalin and forwarded for histopathological study.
Seriated cuts were made with four micrometers of thickness which, placed on blades and stained by the Sirus-Red technique enabled us to evaluate the density, quality and ordering of the collagen ${ }^{33}$. The cuts were evaluated without prior knowledge of the meaning of the codes utilized to identify the samples.

In the Sirus-Red analysis of the cuts, the thickest and most birefringent collagen fibers had a reddish orange color (collagen I); and the thinnest and most dispersed fibers, weakly birefringent, had a greenish coloring (collagen III) ${ }^{33}$. The images were captured by a Sony CCD101 camera and transmitted to a Trinitron Sony color monitor, frozen and digitalized through the oculus TCX board. The images were analyzed using Image-Plus ${ }^{\circledR} 4.5$ for Windows ${ }^{\circledR}$ from MediaCybernetics on a Pentium microcomputer. Five fields enlarged 200x and located on the line of the scar were analyzed in each cut. In each of the fields the percentage of area occupied by the red and yellow fibers (collagen I) and green fibers (collagen III) was calculated. Considering that the other types of collagen constitute small fraction, for practical purposes, the sum of collagens I and III was considered as being the total collagen of the scar.

For comparison of the four groups in this study, the variance analysis was used with a factor (ANOVA) and the LSD test for multiple comparisons, or the non-parametric Kruskal-Wallis test, when appropriate. The condition of normality of the data was evaluated by the Shapiro-Wilks test and the homogeneity of variances by the Levène test. Values of $p \leq 0.05$ indicated statistical significance.

\section{Results}

Eight animals from the $\mathrm{YH}$ group and 8 from the $\mathrm{OH}$ group died during the ninety days prior to the surgery. One hundred and twenty-two were operated on. In the immediate post-operative period, 2 from the $\mathrm{YH}$ group and 2 from the $\mathrm{OH}$ group died. Therefore, 118 animals were left for monitoring.

All the animals induced with streptozocin developed hyperglycemia. The levels were higher after 24 hours, although they remained high until the end of the experiment (Figure 1).

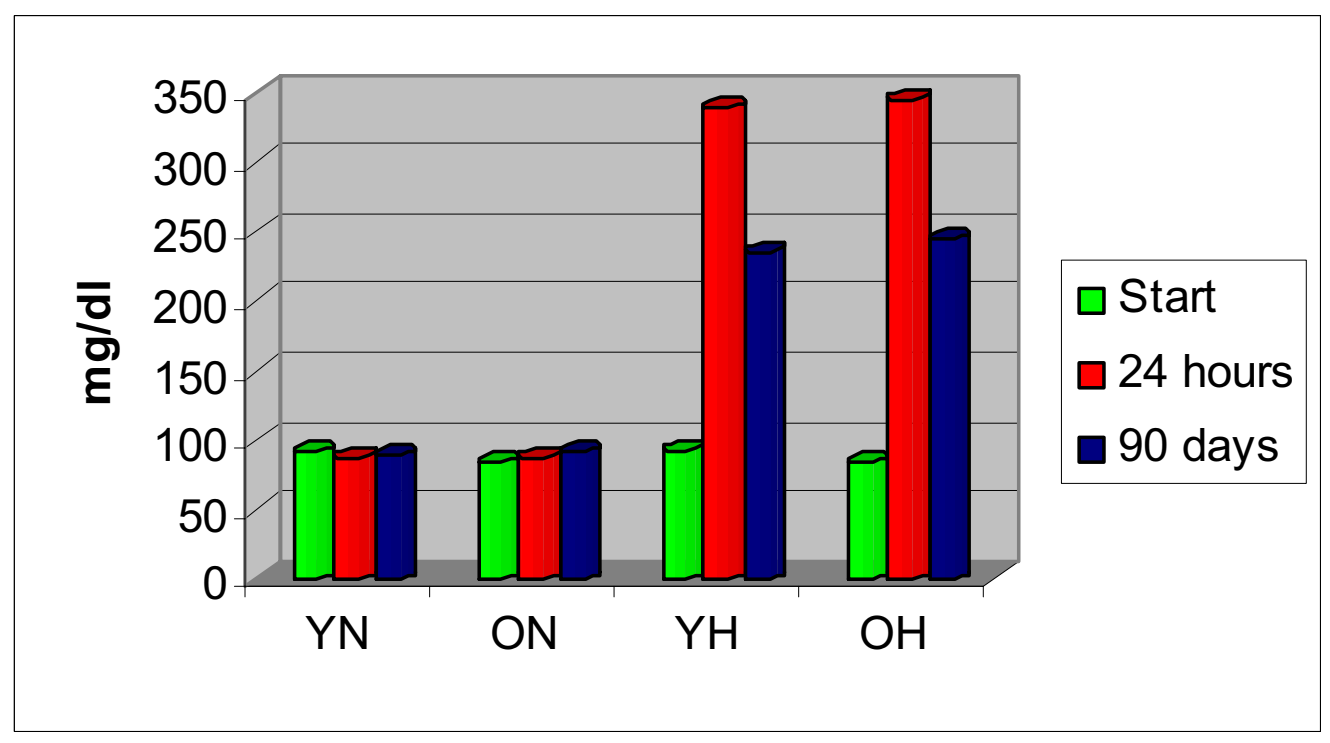

FIGURE 1 - Variation of average levels of glucose in the four groups 
No anastomotic dehiscence was registered and adherences were found, with different intensities, in the anastomoses of all groups.
The anastomoses gained resistance as time passed in the four groups, without any significant difference between them (Figure 2).

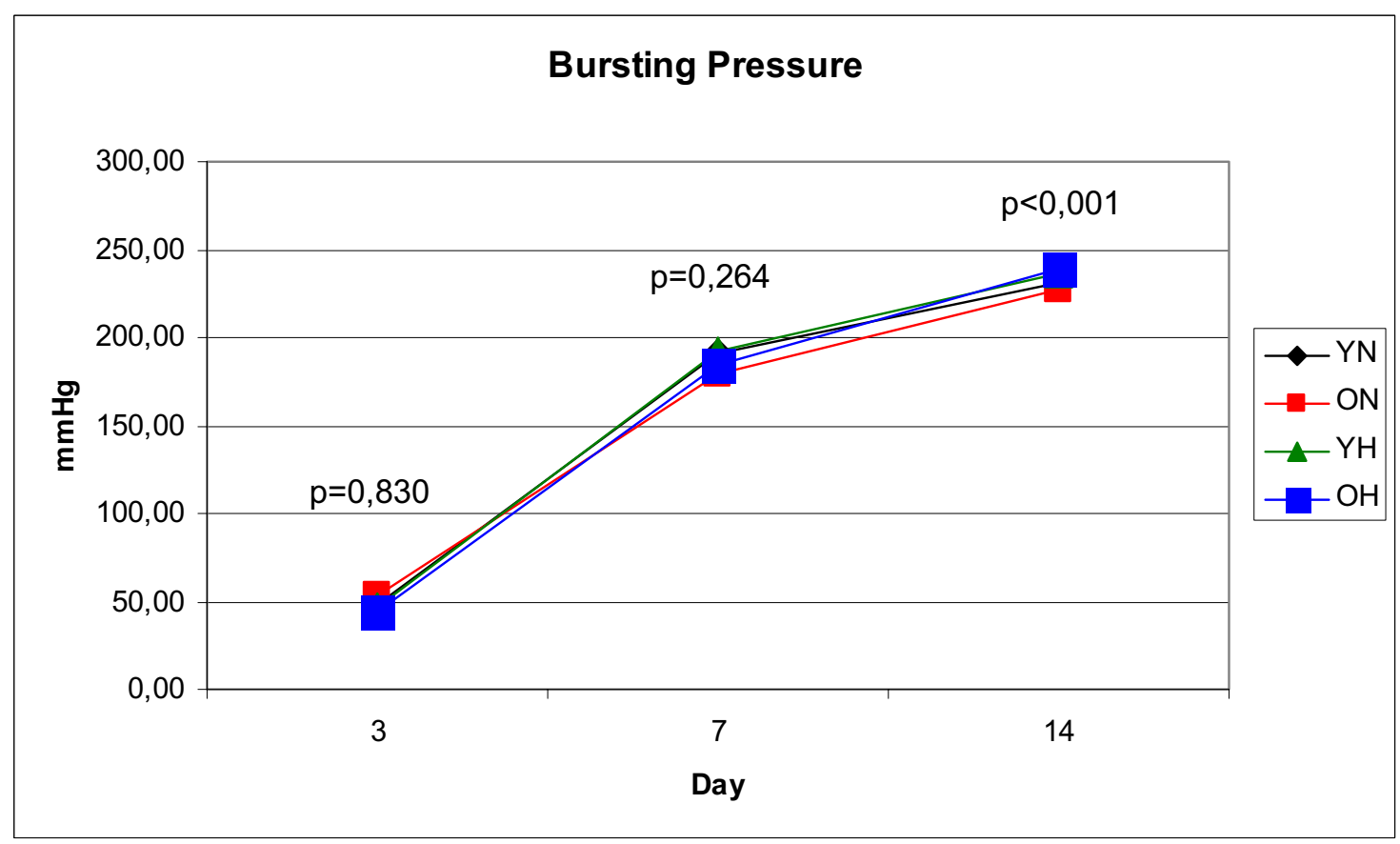

FIGURE 2 - Average of bursting pressure with gain at each time

The values of the total collagen density readings show that there was no difference between the groups in the evaluation on the third day $(\mathrm{p}=0.987)$, which was also the case on the seventh day $(p=0.0439)$. However, there was a significant difference on the fourteenth day $(p<0.001)$. The two by two comparison at this time, showed that there was more collagen in the amastomoses of the young normal animals than in the older hyperglycemic animals $(\mathrm{p}<0.001)$, demonstrating the interference of age and hyperglycemia. Colonic anastomoses in the older normal animals had more collagen than in the older hyperglycemic animals $(p=0.029)$. In this case, as the two groups compared are of older animals, the factor of interference would be age. Comparing the collagen densities between young and old hyperglycemics, we observed that the young ones had more collagen $(\mathrm{p}<0.001)$ (Figure 3$)$.

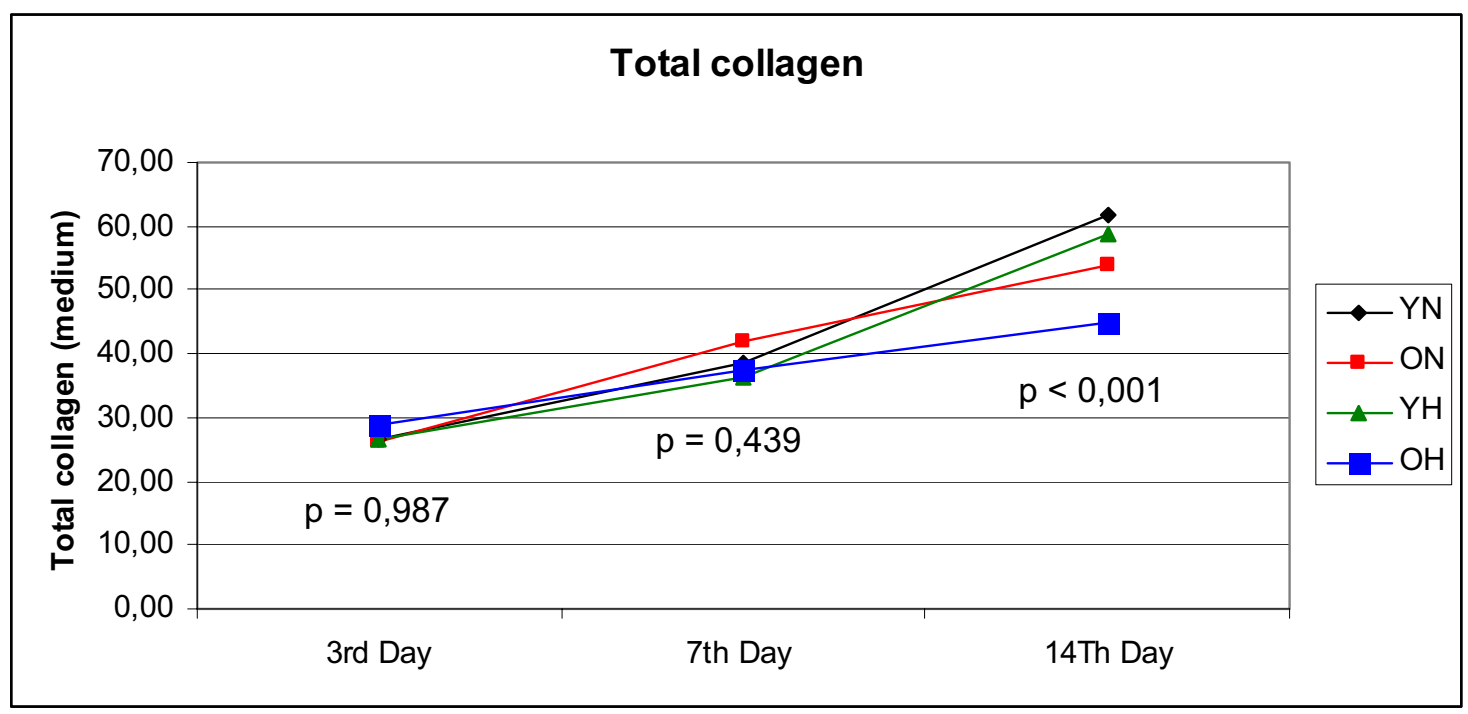

FIGURE 3 - Collagen gain in the four groups at the three times 
Analysis of the collagen fractions enabled us to verify that at the three times studied, the collagen III density was higher than that of collagen I and that the proportion between them was continually modified with the evolving healing process. There was no significant difference in the collagen III density between the groups on the third day $(p=0.191)$, nor on the seventh day $(p=0.773)$. On the fourteenth day, there was a difference between the groups $(\mathrm{p}=0.038)$. Compared two by two, we could see that in the colonic anastomoses of the young animals there was a higher density of collagen III than in the older hyperglycemic animals $(p=0.022)$, showing the interference of age and the levels of glycemia. Comparison of the densities of this fraction of collagen between the old groups showed that the noromglycemics were higher $(\mathrm{p}=0.013)$. In this case the interference of glycemia is evident (Figure 4).

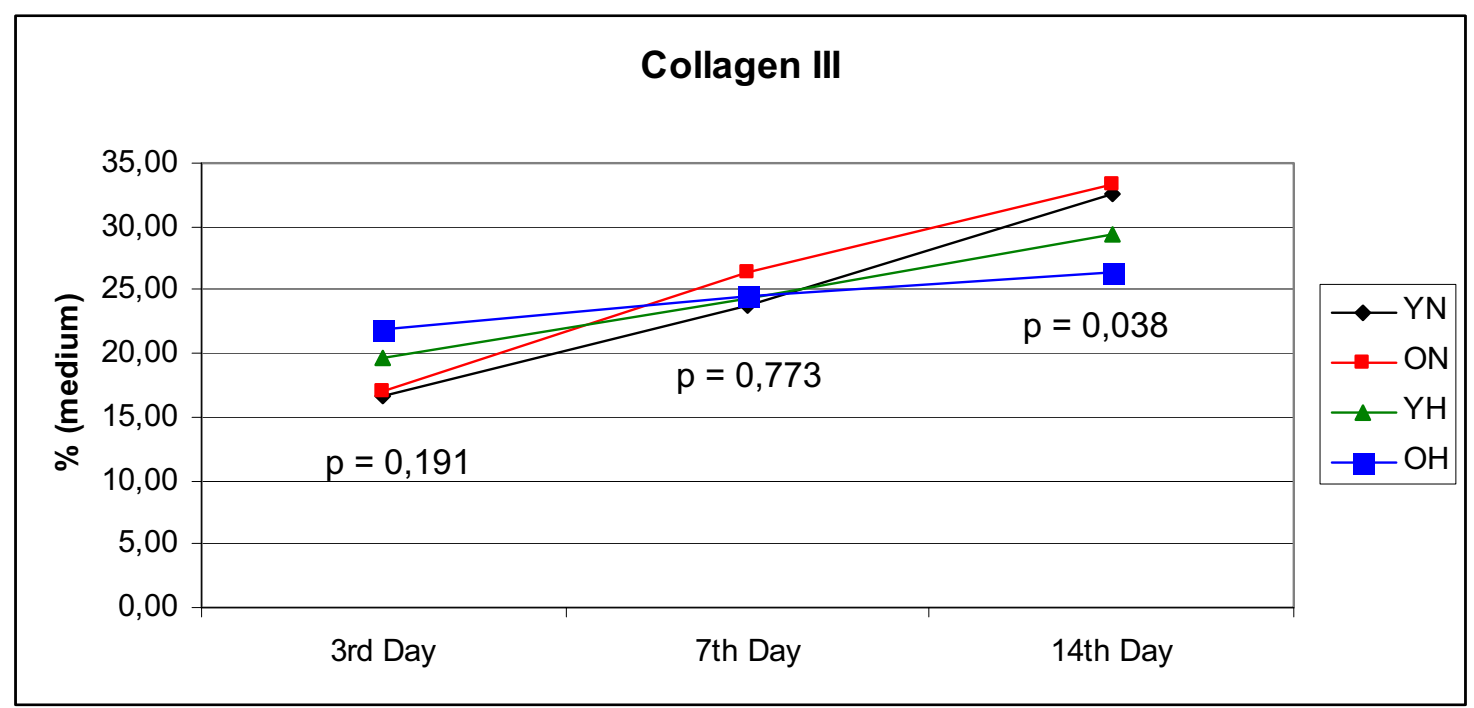

FIGURE 4 - Gain in collagen III in the four groups

Analysis of the collagen I fraction was lower than that of collagen III at all times, although there was a gain with the progress of the healing process. At the first two times, the values were simi$\operatorname{lar}$ (third day $-p=0.100$ and seventh day $-p=0.264$ ). On the fourteenth day, the collagen I density in the anastomoses was different $(\mathrm{p}<0.001)$. For the normoglycemic groups, the colonic anastomoses of the young had more collagen I than the old ( $p=0.002)$, thus the interference of age. Colonic anastomoses in young normal animals had more collagen I than young hyperglycemic animals $(p<0.001)$. In this case, this was evidence of the influence of glycemia. Comparing the colonic anastomoses of young normal animals with the old hyperglycemic, the former had more collagen I $(p<0.001)$, strengthening the hypothesis that age and glycemia would be factors of interference (Figure 5).

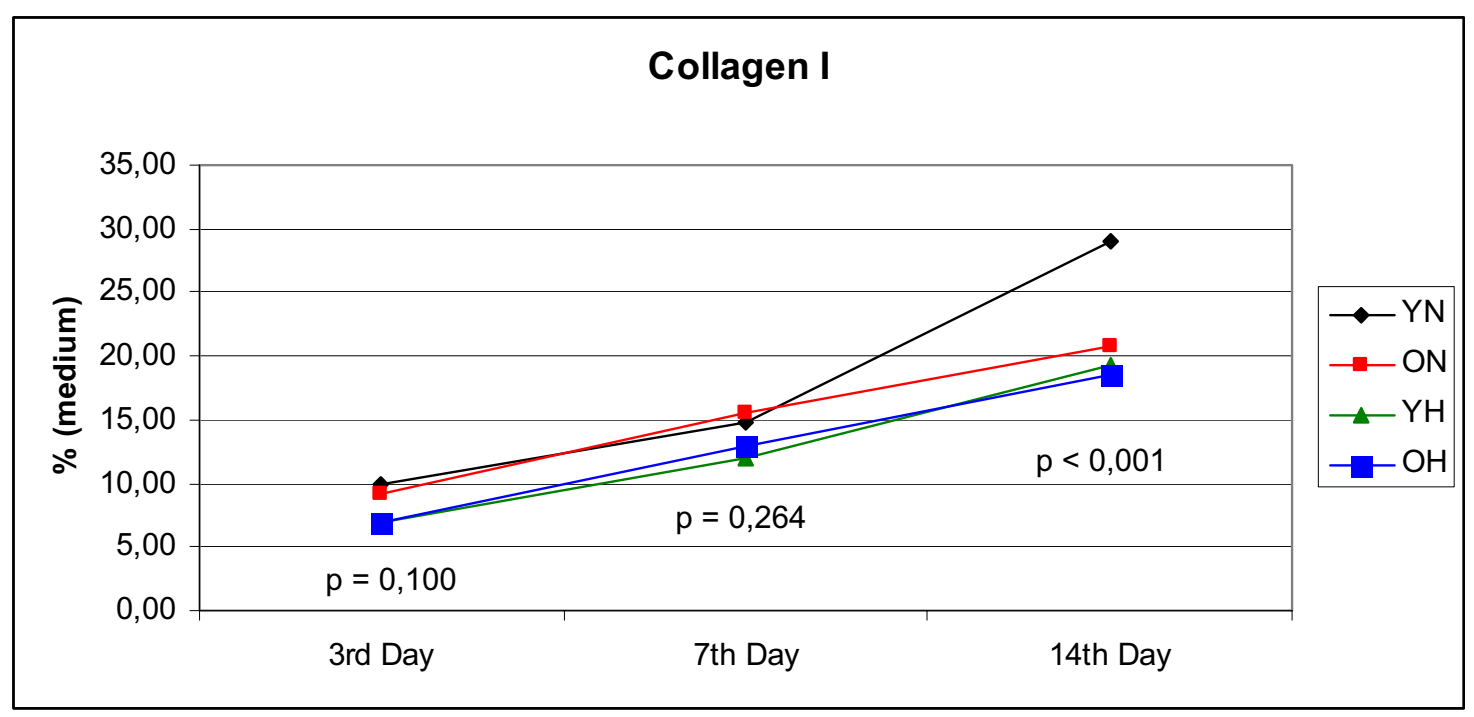

FIGURE 5 - Curve showing gain in collagen I density in the anastomoses of the four groups 


\section{Discussion}

Intolerance of glucose is the most important endocrinal alteration in the elderly population, being around $45 \%$ more frequent than in the younger population ${ }^{34}$.

One of the major consequences of hyperglycemia is nonenzymatic glycosylation of proteins ${ }^{13}$ such as hemoglobin, a albumin, crystalline proteins, collagen, elastin, myelinic proteins and other ${ }^{14}$. There is an accumulation of end products of glycosylation until this deposition is irreversible, leading to structural and functional alterations ${ }^{14,35}$. When these proteins are exposed to high levels of glycemia for some days, the reactions of glycosylation of formed products are still reversible, which is not the case after months of exposure ${ }^{14}$. Hyperglycemia leads to end products of advanced glycosylation which are strengthened by aldolases by covalent reactions of animo-reactive groups. These end products of advanced glycosylation lead to increased oxidative stress and may activate the key to the transcription factor of the nuclear factor that is related to many cellular responses linked to cytokines. Thus these products appear to induce the production of PDGF, TNF- $\alpha$ and IL- $1-\alpha^{36}$. These products may increase cross linking of collagen, inhibiting normal degradation.

A significant alteration has been shown in the degree of collagen glycosylation and its content in injuries after five days of hyperglycemia in rats ${ }^{37}$. This finding implies that recently formed glycosylation products, although reversible, are harmful to the healing process. In this study, after three months of exposure to hyperglycemia, the animals probably had the end products of advanced glycosylation, a fundamental condition for evaluating the effects of hyperglycemia on collagen synthesis and the related effects of healing intestinal anastomoses.

In literature we find less activity of leucocytes with a consequent lower inflammatory response, bactericide capacity and the formulation of granulation tissue ${ }^{9,11,26}$. Komesu et al. ${ }^{26}$ described in rats with diabetes induced by alloxan an inflammatory response with a slower and more prolonged beginning. They also found lower density of neutrophils in the analysis of the third day. When they examined after a longer time, they noted that at the time when they were expecting higher density of macrophages, what they did find was a larger number of neutrophils, confirming a slow and drawn out beginning of the inflammatory phase. The glycoylated hemoglobin has reduced reactivity, with 2.3-dephosphoglycerate, which affects the transport of oxygen and results in tissue hypoxia ${ }^{15}$. If we consider that proline and lysine hydrolyxation depend on oxygen, its lack will result in lower collagen synthesis.

Insulin deficiency in diabetics leads to a reduction in the metabolism of carbohydrates, fats and proteins which are necessary for cellular activities and protein synthesis in the healing process. Insulin is necessary for the entry of glucose in the cells and to remove the energetic need for the synthesis of proteins and to inhibit lipolysis. Glucose is the main energy supply for the fibroblasts and for the polymorphonuclears. Thus, diabetics have reduced activities in these cells and therefore in healing ${ }^{38}$. There is a compromise of the chemotaxis, phagocytosis and bactericide capacity ${ }^{9,27}$, reduced expression of shock proteins ${ }^{39}$, lower antioxidant production and increased production of oxygen free radicals $\mathrm{s}^{40,41}$ during the initial phase of the process, which adversely affects healing. Furthermore, there is depletion of growth factors ${ }^{5-8,11,12}$, increased levels of glucocorticoids ${ }^{42}$, loss of cellular proliferation and increased regulation of apoptosis ${ }^{10,11,43-45}$, characteristics of the later phase of healing in diabetics, which results in poor granulation tissue formation ${ }^{11}$.

Franzén and Roberg ${ }^{46}$, studying healing in diabetic rats, showed that fibroblasts have a lower number of cytoplasmatic protrusions with lower surface density of the plasmatic membrane, which indicates the reduced motility of these cells, a condition linked to reduced healing. Velander et al. ${ }^{12}$, working with pigs that had diabetes induced by streptozotocin, observed a significant fall of the levels of TGF- $\beta$ and IGF-1 on the seventh day, the latter being an important stimulator of the proliferation of keratinocytes and fibroblasts.

Minimum disturbances in the synthesis balance, deposition, degradation and remodeling of the collagen may result in a deficiency in the healing of the anastomosis ${ }^{47}$. The collagen fibers are responsible for the integrity of the intestinal wall ${ }^{48}$ and the organization of fibers is essential to understanding the anastomotic healing process, although the quality, in comparison with the quantity of collagen fibers, is what plays the fundamental role in maintaining the integrity of the intestinal wall during this process ${ }^{49}$.

Several authors have reported in experimental studies that there is lower resistance and less collagen deposition in anastomoses done in the stomach, the ileum and the colon in animals with hyperglycemia ${ }^{19-23,50}$.

Despite significant advances in the knowledge of the healing process for colonic anastomoses, there is a limited number of studies demonstrating the relationship between this healing mechanism and ageing and high levels of glycemia.

Stoop et al. ${ }^{51}$ reported that colonic anastomoses had equal resistance in young and old animals and that the collagen content was higher in the old. Seyer-Hansen et al. ${ }^{52}$, studied colon anastomoses in old and diabetic rats and concluded that resistance was not reduced with age and with diabetes. Meanwhile, Onodera et $a l^{23}$ tested the integrity of colon anastomoses in diabetic rats and stated that resistance was significantly compromised with less accumulation of collagen I in the evaluation after seven days and that these parameters were the same after fourteen days.

In a previous study in our line of research we observed that the inflammatory process was extended over a longer period of time in the anastomoses of older rats, that resistance was similar and that the collagen content up to the seventh day was also resistant, becoming greater in colonic anastomoses in young rats on the fourteenth day ${ }^{2}$. In another study, re-epithelization was seen to occur earlier in the anastomoses of young normoglycemic rats, as was the case with neovascularization ${ }^{3}$. According to Spravchikov et $a .^{43}$ in high concentrations of glucose, the effects of IGF-1 in the absorption of glucose by the keratinocytes and its proliferation and differentiation would be inhibited.

In this study the previous information was confirmed that resistance was not being affected, confirming the findings described by Seyer-Hansen et al. ${ }^{52}$. It was possible to see that colonic anastomoses in young and old normo or hyperglycemic rats had similar collagen density up to the seventh day. However, on the fourteenth day, the densities were different. There was less collagen in the anastomoses of the old and hyperglycemic animals $(p<0.001)$. In this case, age and hyperglycemia influenced the result. It was also seen that the anastomoses in older normoglycemic animals had more collagen than the hyperglycemic animals $(p=0.029)$ and in this case the factor responsible for this must have been the glycemia level. 
By analyzing both young and old hyperglycemic rats, a lower density of collagen was found in the anastomoses of the latter and therefore age must be affecting the process. If we consider that the fraction of collagen I was higher in the anastomoses of the young normoglycemic rats than in the older normo and hyperglycemic rats, it is possible to suppose that not only was the collagen density affected but also the scar maturation.

\section{Conclusions}

1. Resistance of anastomosis is not affected by age or by hyperglycemia;

2. Collagen density is not affected in the early stages;

3. Collagen density is affected in later stages both by age and by high levels of glycemia;

4. Both fractions of collagen are affected, especially collagen I, which means that there is a delay in scar maturation.

\section{References}

1. Beck E, Duckert F, Ernst M. The influence of fibrin stabilizing factor on the growth of fibroblasts in vitro and wound healing. Thromb Diath Haemmorrh. 1961;6:485-91.

2. Biondo-Simões MLP. Os efeitos do envelhecimento na cicatrização: avaliação da parede abdominal e de anastomoses colônicas, em ratos [Tese]. Curitiba: Pontifícia Universidade Católica do Paraná; 2001.

3. Nóbrega NL. Efeitos da hiperglicemia e do envelhecimento sobre a angiogênese e a reepitelização de anastomoses colônicas, em ratos. [Dissertação]. Curitiba: Pontifícia Universidade Católica do Paraná; 2005. 4. Fahey TJ, Sadaty A, Jones WG, Barber A, Smoller B, Shires GT. Diabetes impairs the late inflammatory response to wound healing. J Surg Res. 1991; 50(4):308-13.

5. Werner S, Breeden M, Hübner G, Greenhalgh DG, Longaker MT. Induction of keratinocyte growth factor expression is reduced and delayed during wound healing in the genetically diabetic mouse. J Invest Dermatol. 1994; 103(4):469-12.

6. Frank S, Hübner G, Breier G, Longaker MT, Greenhalgh DG, Werner S. Regulation of vascular endothelial growth factor expression in cultured keratinocytes. Implications for normal and impaired wound healing. J Biol Chem. 1995; 270(21):12607-13.

7. Doxey DL, Ng MC, Dill RE, Jacopino AM. Platelet-derived growth factor levels in wounds of diabetic rats. Life Sci. 1995; 57(11):1111-23.

8. Brown DL, Kane CD, Chernausek SD, Greenhalgh DG. Differential expression and localization of insulin-like growth factors I and II in cutaneous wounds of diabetic and nondiabetic mice. Am J Phatol. 1997; 151(3):715-24.

9. King L. Impaired wound healing in patients with diabetes. Nurs Stand. 2001; 15(38):39-45

10. Galkowska H; Wojewodzka U; Olszewski WL. Chemokines, cytokines, and growth factors in keratinocytes and dermal endothelial cells in the margin of chronic diabetic foot ulcers. Wound Repair Regen. 2006;14(5):558-65.

11. Brem H, Tomic-Canic M. Cellular and molecular basis of wound healing in diabetes. J Clin Invest. 2007; 117(5):1219-22.

12. Velander P, Theopold C, Hirsch T, Bleiziffer O, Zuhaili B, Fossum M, Hoeller D, Gheerardyn R, Chen M, Visovatti S, Svensson H, Yao F, Eriksson E. Impaired wound healing in an acute diabetic pig model and the effects of local hyperglycemia. Wound Repair Regen. 2008; 16(2):288-93.

13. McFarland KF, Catalano EW, Day JF, Thorpe SR, Baynes JW. Nonenzymatic glucosylation of serum proteins in diabetes mellitus. Diabetes. 1979; 28(11):1011-4.

14. Vlassara H, Brownlee M, Cerami A. Nonenzymatic glycosylation: role in the pathogenesis of diabetic complications. Clin Chem. 1986; 32(10 Suppl):B37-41.
15. Silhi N. Diabetes and wound healing. J Wound Care. 1998; 7(1):47-51. 16. Sharma A, Singh AK, Warren J, Thangapazham RL, Maheshwari RK. Differential regulation of angiogenic genes in diabetic wound healing. J Invest Dermatol. 2006; 126(10):2323-31.

17. Witte MB, Barbul A. Repair of full-thickness bowel injury. Crit Care Med. 2003; 31 (8 Suppl):S538-46.

18. Gottrup F, Andreassen TT. Healing of incisional wounds in stomach and duodenum: influence of experimental diabetes. J Surg Res. 1981;31(1):61-8.

19. van der Hem LG, Verhofstad MH, Bocken JA, van der Vliet JA, Hendriks T. Pancreatic islet transplantation prevents impaired healing of intestinal anastomoses in diabetes. Transplant Proc. 1994; 26(2):660-1.

20. Verhofstad MH; Hendriks T. Diabetes impairs the development of early strength, but not the accumulation of collagen, during intestinal anastomotic healing in the rat. Br J Surg. 1994; 81(7):1040-5.

21. Verhofstad MHJ, Hendriks TH. Complete prevention of impaired anastomotic healing in diabetic rats requires preoperative blood glucose control. Br J Surg. 1997; 83(12):1717-21.

22. Takeuchi K, Takehara K, Tajima K, Kato S, Hirata T. Impaired healing of gastric lesions in streptozotocin-induced diabetic rats: effect of basic fibroblast growth factor. J Pharmacol Exp Ther. 1997; 281(1):200-7.

23. Onodera H, Ikeuchi D, Nagayama S, Imamura M. Weakness of anastomotic site in diabetic rats is caused by changes in the integrity of newly formed collagen. Dig Surg. 2004; 21(2):146-51.

24. Chittenden SJ; Shami SK. Microvascular investigations in diabetes mellitus. Postgrad Med J.1993; 69(B12):419-28.

25 . Nishigaki A. Experimental studies of skin wound healing process by first intention in streptozotocin-induced diabetes mellitus rats. Shikwa Gakuho. 1989; 89(4):793-822.

26. Komesu MC, Tanga MB, Buttros KR, Nakao C. Effects of acute diabetes on rat cutaneous wound healing. Pathophysiology. 2004; 11:63-7.

27. Alba-Loureiro TC, Hirabara SM, Mendonça JR, Curi R, Pithon-Curi TC. Diabetes causes marked changes in function and metabolismo $f$ rat neutrophils. J Endocrinol. 2006; 188(2):295-303.

28. www.diabetes.org.br. Acesso em 14 jul 2008.

29. www.ibge.gov.br. Acesso em 15 jul 2008.

30. www.inca.gov.br. Acesso em 15 jul 2008.

31. Sharp PE, La Regina MC. The laboratory rat. Washington: CRC Press; 1998.

32. Conselho Federal de Medicina Veterinária. Resolução n 714 de 20 de junho de 2002. Dispõe sobre procedimentos e métodos de eutanásia em animais, e dá outras providências. Diário Oficial da Republica Federativa do Brasil, Brasília, 21 jun. 2002.

33. Junqueira LC, Cossemelli W, Bretani R. Differencial staining of collagen type I, II and III by sirius red and polarization microscopy. Arch Histol Jpn. 1978; 41(3):267-74.

34. Perry HM. The endocrinology of aging. Clin Chem. 1999; 45(8Pt 2):1369-76.

35. Koenig RJ, Cerami A. Hemoglobin A Ic and diabetes mellitus. Annu Rev Med. 1980; 31:29-34.

36. Kirstein M, Brett J, Radoff S, Ogawa S, Stern D, Vlassara H. Advanced protein glycosylation induces transendothelial human monocyte chemotaxis and secretion of platelet-derived growth factor: role in vascular disease of diabetes and aging. Proc Natl Acad Sci USA. 1990; 87(22):9010-4.

37. Black CT, Hennessey PJ, Ford EG, Andrassy RJ. Protein glycosylation and collagen metabolism in normal and diabetic rats. J Surg Res. 1989; 47(3):200-2.

38. Ekmektzoglou KA, Zografos G. A concomitant review of the effects of diabetes mellitus and hypothyroidism in wound healing. World Gastroenterol. 2006; 12(17):2721-9.

39. McMurtry AL; Cho K; Young LJ; Nelson CF; Greenhalgh DG. Expression of HSP70 in healing wounds of diabetic and nondiabetic mice. J Surg Res. 1999; 86(1):36-41.

40. Mohan IK; Das UN. Effect of L-arginine-nitric oxide system on chemical-induced diabetes mellitus. Free Radic Biol Med. 1998; 25(7):757-65. 
41. Haluzik M; Nedvídková J; Skrha J. Treatment with the NO-synthase inhibitor, methylene blue, moderates the decrease in serum leptin concentration in streptozotocin-induced diabetes. Endocr Res. 1999; 25(2):163-71. 42. Bitar MS. Insulin-like growth factor-1 reverses diabetes-induced wound healing impairment in rats. Horm Metab Res. 1997; 29(8):383-6.

43. Spravchikov N, Sizyakov G, Gartsbein M, Accili D, Tennenbaum T, Wertheimer E. Glucose effects on skin keratinocytes: implications for diabetes skin complications. Diabetes. 2001; 50(7):1627-35.

44. Hehenberger K; Heilborn JD; Brismar K; Hansson A. Inhibited proliferation of fibroblasts derived from chronic diabetic wounds and normal dermal fibroblasts treated with high glucose is associated with increased formation of 1-lactate. Wound Repair Regen. 1998; 6(2):135-41.

45. Darby IA; Bisucci T; Hewitson TD; MacLellan DG. Apoptosis is increased in a model of diabetes-impaired wound healing in genetically diabetic mice. Int J Biochem Cell Biol. 1997; 29(1):191-200.

46. Franzén LE, Roberg K. Impaired connective tissue repair in streptozotocin-induced diabetes shows ultrastructural signs of impaired contraction. J Surg Res. 1995, 58(4):407-14.
47. Oxlund H, Christensen H, Seyer-Hansen M, Andreassen TT. Collagen deposition and mechanical strength of colon anastomoses and skin incisional wounds of rats. J Surg Res. 1996; 66(1):25-30.

48. Hendriks T, Mastboom WJB. Healing of experimental intestinal anastomoses: parameters for repair. Dis Colon Rectum. 1990; 33(10):891-901. 49. Rabau MY, Hirshberg A, Hiss Y, Dayan D. Intestinal anastomosis healing in rat: collagen concentration and histochemical characterization by picrosirius red stainning and polarizing microscopy. Exp Mol Pathol. 1995; 62(3):160-5.

50. Verhofstad MH, Lange WP, van der Laak JAWM, Verhofstad AAJ, Hendriks T. Microscopic analysis of anastomotic healing in the intestine of normal and diabetic rats. Dis Colon Rectum. 2001; 44(3):423-31.

51. Stoop MJ, Dirksen R, Hendriks T. Advanced age alone does not suppress anastomotic healing in the intestine. Surgery. 1996; 119(1):15-9.

52. Seyer-Hansen M, Andreassen TT, Oxlund H. Strength of colonic anastomoses and skin incisional wounds in old rats - influence by diabetes and growth hormone. Growth Horm IGF Res. 1999; 9(4):254-61.

Conflict of interest: none Financial source: $\mathrm{CNPq}$

\section{Correspondence:}

Maria de Lourdes Pessole Biondo-Simões

Rua Ari José Valle, 1987

82030-000 Curitiba - PR Brazil

Phone: (55 41)3297-4359

biondo@avalon.sul.com.br

Received: October 20, 2008

Review: December 15, 2008

Accepted: January 19, 2009

\section{How to cite this article}

Biondo-Simões MLP, Biondo-Simões R, Ioshii SO, Barczak DS, Tetilla MR. Effects of hyperglycemia and ageing on the healing of colonic anastomoses in rats. Acta Cir Bras. [serial on the Internet] 2009 Mar-Apr;24(2). Available from URL: http://www.scielo.br/acb

*Color figures available from www.scielo.br/acb 